\title{
БИОЛОГИЧЕСКАЯ СТРУКТУРА КЕТЫ ONCORHYNCHUS KETA МАТЕРИКОВОГО ПОБЕРЕЖЬЯ ОХОТСКОГО МОРЯ
}

\author{
В. В. Волобуев, В. А. Грушинец \\ ФГБНУ «Магаданский научно-исследовательский институт рыбного хозяйства и океанографии», \\ 2. Магадан \\ E-mail:volobuev@magadanniro.ru
}

\begin{abstract}
Рассмотрена биологическая структура взрослой кеты как в смешанных выборках, так и раздельно для двух экологических форм - ранней и поздней из рек материкового побережья Охотского моря. Представлены сведения о возрастной, размерно-весовой структуре, соотношении полов, плодовитости, упитанности, степени зрелости половых продуктов. Рассмотрено влияние некоторых биоценотических факторов на биологическую структуру кеты.
\end{abstract}

Ключевые слова: кета, возрастная структура, размер, масса тела, упитанность, зрелость.

DOI: 10.34078/1814-0998-2019-2-104-116

\section{ВВЕДЕНИЕ}

Кета Oncorhynchus keta на Дальнем Востоке является вторым по численности и значимости в промысле видом тихоокеанских лососей после горбуши O. gorbuscha. Ее запасы и вылов значительно увеличились в 2000-х гг. Так, ее вылов с 2001 по 2015 г. возрос почти в 5 раз: с 29.6 до 142.4 тыс. т. Кета представлена на Дальневосточном рыбохозяйственном бассейне крупными региональными комплексами, стадами и локальными популяциями. Кроме того, известна ее внутривидовая неоднородность: дифференциация на несколько экологических форм (Берг, 1948; Смирнов А. И., 1975). На основании сроков нерестовой миграции и морфологического сходства кеты северных популяций некоторые авторы считают, что северо-восточную часть Азии и арктическое побережье материка населяет только летняя кета (Правдин, 1940; Андрияшев, 1954; Леванидов, 1969; Иванков, 1970; Куликова, 1972; Черешнев, 1980, 1981). Однако имеются данные, свидетельствующие об экологической и внутривидовой неоднородности кеты, обитающей на Камчатке, материковом побережье Охотского моря и в бассейне р. Анадырь (Волобуев, 1983, 1986; Николаева, Овчинников, 1988; Путивкин, 1989, 1999; Николаева и др., 1995; Кузищин и др., 2010; Кульбачный, Иванков, 2011).

На материковом побережье Охотского моря некоторые авторы также предполагали возмож-

(C) Волобуев В. В., Грушинец В. А., 2019 ность существования летней и осенней форм кеты, размножающихся на русловых и ключевых нерестилищах (Правдин, 1940; Костарев, 1970). Воспроизводящиеся в указанном районе формы кеты иногда трудно различимы по срокам анадромной миграции, которые могут перекрываться. Однако изучение репродуктивной экологии показывает внутривидовую гетерогенность кеты.

Установлено, что в реках материкового побережья Охотского моря воспроизводятся две формы кеты - ранняя и поздняя, различающиеся по особенностям экологии и морфобиологическим признакам (Волобуев, 1983, 1984, 1986; Волобуев и др., 1992). Ранняя форма кеты воспроизводится на водах подруслового потока, поздняя - на ключевых нерестилищах, образуемых выходами таликовых или глубинных подмерзлотных вод (Волобуев, Рогатных, 1997; Волобуев, Марченко, 2011).

Ранняя кета воспроизводится как в крупных реках материкового побережья Охотского моря (Ола, Кава, Кухтуй, Охота), протяженностью до 200-400 км, так и в малых (Иткилан, Мотыклейка, Быструха и др.) длиной 30-50 км. Ранняя кета мигрирует на нерест в июне-июле, поздняя - с конца июля по ноябрь. Нерест ранней кеты происходит в июле - начале августа в русловой части рек и притоках первого и второго порядка. Поздняя кета более многочисленна в бассейнах крупных рек, где разнообразие условий для ее воспроизводства выше. Она размножается в ключевых протоках и лимнокренах в сентябре-октябре. 
В настоящее время в крупных реках материкового побережья Охотского моря преобладает, как правило, поздняя, в малых - ранняя форма кеты.

Помимо особенностей гидрологического режима нерестилищ, кета обеих форм различается и по биологическим характеристикам. Ранняя кета мельче поздней. Однако самки ранней кеты характеризуются большей плодовитостью по сравнению с одноразмерными особями поздней кеты. Это обусловлено меньшими размерами икринок, что характерно для летней расы вида (Бирман, 1952).

На материковом побережье Охотского моря кета является вторым по численности видом после горбуши и имеет важное значение в лососевом промысле. За последнее десятилетие ее доля в подходах лососей по урожайным (нечетным) годам возвратов горбуши колебалась от 5.7 до $14.2 \%$, а уловы достигали 2.5 тыс. т. Цель настоящей работы - дать характеристику биологической структуры стада кеты материкового побережья Охотского моря.

\section{МАТЕРИАЛ И МЕТОДИКА}

Материал для работы собирали с 60-х гг. $\mathrm{XX}$ в. Работы проводили на 12 нерестовых лососевых реках побережья: Гижига, Наяхан, Туманы, Яма, Ола, Армань, Яна, Тауй, Чёломджа, Чукчинка, Кухтуй, Охота. Ежегодно с каждой реки на полный биологический анализ собирали от 500 до 1200 экз. кеты. Всего для подготовки публикации использованы данные о более чем 125 тыс. экз. кеты. Сбор материалов по биологической структуре кеты проводили ежегодно на одних и тех же реках в режиме мониторинга. Пробы на биологический анализ собирали в течение всей анадромной миграции с дискретностью 5 дней. Объем одной стандартной пробы составлял 100 экз. Биологические анализы включали: определение пола, измерения рыбы (длина по Смитту и длина тушки), массу целой и массу рыбы без внутренностей, массу гонад, пробы чешуи, навески икры для определения абсолютной плодовитости и массы икринок (Правдин, 1966). Возраст определяли по чешуе.

\section{РЕЗУЛЬТАТЫ И ОБСУЖДЕНИЕ}

Возрастной состав. Кета, воспроизводящаяся в реках побережья, возвращается на нерест в возрасте $1+-6+$ лет (табл. 1). Преобладающие возрастные группы представлены рыбами $3+$ и 4+ лет - более $90 \%$. Самые малочисленные возрастные группы представлены особями $1+$ и $6+$ лет.

За период наблюдений средний возраст кеты в подходах увеличивался с середины 1990-х гг. Особенно возрос он в 2006-2013 гг. - до 3.834.00 лет (табл. 2). По-видимому, это обусловлено наблюдаемым во второй половине 19902000-х гг. замедлением созревания поколений и возвратом значительной части кеты в возрасте $4+-$ $5+$ лет вместо обычных $3+-4+$ лет. При изучении возраста созревания кеты в подходах установлено, что в 1960-1980-е гг. большая часть рыб (до 60-70\%) созревала и возвращалась на нерест в 4-летнем возрасте (3+). Однако в 2000-е гг. доля таких рыб в подходах в отдельных реках снизилась до 30-24\% (см. табл. 2).

Исследованиями, проведенными в западной части Берингова моря (Бугаев и др., 2009), установлено, что в этом районе Северной Пацифики доминируют стада российской и японской кеты с перекрыванием их ареалов морского нагула.

Не исключено, что увеличение возраста созревания североохотоморской кеты обусловлено плотностно-зависимыми отношениями, возникшими между ее стадами и кетой японского происхождения в Северной Пацифике, где происходит перекрывание их районов нагула. Японские исследователи (Ishida et al., 1993) допускают, что это могло произойти за счет резко возросшей численности японской кеты заводского происхождения. Так, среднегодовой прибрежный вылов кеты в Японии с 2.9 млн рыб в 1950-х гг. возрос

\section{Таблица 1. Осредненный возрастной состав кеты материкового побережья Охотского моря} за 1961-2013 гг., \%

Table 1. Average age composition of the chum salmon at the continental coast of the Sea of Okhotsk in 1961-2013, \%

\begin{tabular}{|l|c|c|c|c|c|c|}
\hline \multirow{2}{*}{ *Стадо (река) } & \multicolumn{7}{|c|}{ Возраст, лет } \\
\cline { 2 - 7 } & $1+$ & $2+$ & $3+$ & $4+$ & $5+$ & $6+$ \\
\hline Гижигинское & - & 2.1 & 52.6 & 41.9 & 3.3 & 0.1 \\
(Гижига, Наяхан) & & 2.5 & 49.4 & 43.9 & 4.1 & 0.1 \\
Ямское (Яма) & ед. & 2.4 & 50.2 & 42.0 & 5.2 & 0.2 \\
Тауйское (Тауй) & ед. & 4.0 & 48.2 & 43.5 & 4.3 & ед. \\
Охотское (Кухтуй) & - & 2.8 & 50.1 & 42.8 & 4.2 & 0.1 \\
\hline \multicolumn{1}{|c|}{ Среднее } & ед. & 2.2 & \\
\hline
\end{tabular}

*Характеристика и дифференциация стад кеты материкового побережья Охотского моря приведены ранее (Волобуев и др., 2005). Здесь и в табл. 1, 3, 6 прочерки означают отсутствие данных. 
Таблица 2. Доля рыб в возрасте 3+ (\%) и средний возраст (в скобках) североохотоморской кеты в подходах (осредненные данные по пятилетиям)

Table 2. Fish share at the age of $3+(\%)$ and the average age (in brackets) of the chum salmon in the Northern Sea of Okhotsk in the returns (averaged data by five-year periods)

\begin{tabular}{|c|c|c|c|c|}
\hline \multirow{2}{*}{ Годы } & \multicolumn{5}{|c|}{ Река } \\
\cline { 2 - 5 } & Гижига & Яма & Тауй & Кухтуй \\
\hline $1961-1965$ & $61.2(3.42)$ & $57.5(3.43)$ & $52.5(3.48)$ & $48.2(3.65)$ \\
$1966-1970$ & $52.3(3.46)$ & $64.8(3.30)$ & $59.9(3.29)$ & $61.1(3.34)$ \\
$1971-1975$ & $68.0(3.26)$ & $65.0(3.30)$ & $69.9(3.27)$ & $38.4(3.45)$ \\
$1976-1980$ & $59.4(3.40)$ & $54.2(3.42)$ & $59.6(3.15)$ & $56.7(3.39)$ \\
$1981-1985$ & $61.9(3.30)$ & $48.1(3.48)$ & $62.9(3.32)$ & $51.4(3.47)$ \\
$1986-1990$ & $51.6(3.48)$ & $52.2(3.51)$ & $59.6(3.34)$ & $41.6(3.68)$ \\
$1991-1995$ & $52.9(3.45)$ & $43.7(3.56)$ & $38.3(3.68)$ & $52.8(3.70)$ \\
$1996-2000$ & $52.0(3.59)$ & $42.9(3.48)$ & $49.9(3.70)$ & $46.4(3.55)$ \\
$2001-2005$ & $47.2(3.53)$ & $37.9(3.69)$ & $40.7(3.67)$ & $42.0(3.60)$ \\
$2006-2010$ & $29.2(3.79)$ & $30.1(3.83)$ & $31.7(3.77)$ & $45.9(3.59)$ \\
$2011-2013$ & $48.4(3.58)$ & $33.4(3.73)$ & $24.2(4.00)$ & $48.5(3.55)$ \\
$1961-2013$ & $53.1(3.48)$ & $40.8(3.52)$ & $49.9(3.52)$ & \\
\hline
\end{tabular}

Примечание. По охотскому стаду (р. Кухтуй) дополнительно использованы данные, приведенные в прогнозах «Лосось2000»- «Лосось-2014».

до 36.3 млн рыб в 1980-х гг. и составлял около $60 \%$ общего вылова кеты в Северной Пацифике. При этом авторы отмечали значительное увеличение среднего возраста созревания и снижение средней массы тела у японской кеты.

Роста запасов российской кеты в этот период не отмечено. Тем не менее существует вероятность того, что увеличение численности японской кеты обусловило замедление темпов ее роста в океане из-за высокой плотности нагульных скоплений и внутривидовой пищевой конкуренции.

Установлено, что с увеличением численности подходов увеличивается возраст созревания и снижаются основные биологические показатели североохотоморской кеты (размер, масса тела и плодовитость), что, по-видимому, также сопряжено с ростом численности кеты японского происхождения, внутри- и межвидовой пищевой конкуренцией (Волобуев, Волобуев, 2000; Volobuev, 2000).

При рассмотрении динамики возрастного состава кеты в течение анадромной миграции в одну из крупных нерестовых рек побережья (р. Чёломджа, басс. р. Тауй) следует отметить, что в начале нерестового хода преобладают рыбы старшего возраста - 4+ лет, к середине хода их доля снижается, затем большинство начинают составлять 4-летние рыбы (3+). В середине конце нерестовой миграции в уловах появляются 3-летние особи (2+) (табл. 3). Вследствие увели-

Таблица 3. Динамика возрастного состава кеты в течение анадромной миграции в р. Чёломджа, \%

Table 3. Dynamics of the chum salmon age composition during anadromous migration to the Chelomdzha River, \%

\begin{tabular}{|c|c|c|c|c|c|}
\hline \multirow{2}{*}{ Дата взятия пробы } & \multicolumn{4}{|c|}{ Доля рыб в возрасте } & \multirow{2}{*}{$\mathrm{N}$, экз. } \\
\hline & $2+$ & $3+$ & $4+$ & $5+$ & \\
\hline & \multicolumn{4}{|c|}{ р. Чёломджа (устье) } & \\
\hline 6 августа & - & 44.4 & 55.6 & - & 36 \\
\hline 11 августа & - & 47.9 & 52.1 & - & 48 \\
\hline 20 августа & 1.0 & 56.6 & 42.4 & - & 99 \\
\hline 29 августа & 3.0 & 70.7 & 26.3 & - & 99 \\
\hline 4 сентября & 18.0 & 62.0 & 24.0 & 1.0 & 100 \\
\hline \multirow[t]{2}{*}{11 сентября } & 17.9 & 57.7 & 24.4 & - & 78 \\
\hline & \multicolumn{4}{|c|}{ p. Чёломджа (Хурэнское нерестилище, 100 км от устья) } & \\
\hline 1 октября & 5.0 & 65.0 & 30.0 & - & 50 \\
\hline 14 октября & 4.0 & 70.0 & 26.0 & - & 50 \\
\hline 24 октября & 8.3 & 64.6 & 27.1 & - & 50 \\
\hline 3 ноября & 10.3 & 69.0 & 20.7 & - & 31 \\
\hline
\end{tabular}


чения в подходах доли самок и более мелких рыб младшего возраста (2+) от начала к концу нерестового хода уменьшаются средние показатели длины и массы тела кеты. Сходная динамика в соотношении рыб разных возрастных групп наблюдается и при подходах на нерестилища в течение октября - начале ноября.

Длина и масса тела. Минимальная длина североохотоморской кеты составляет 43, максимальная - 86 см, масса тела, соответственно, 1.21 и 10.35 кг. Средняя длина варьирует от 60 до 65 см, масса - от 3.1 до 3.8 кг (табл. 4). У кеты североохотоморского побережья самцы, как правило, крупнее самок. При сравнении средних показателей длины и массы тела основных популяций побережья наиболее крупная кета отмечена в р. Яма - 65.4 см и 3.78 кг. Отметим, что и в 1960-1970-е гг. (Клоков, 1970, 1973) наибольшими длиной и массой тела также выделялась кета p. Яма. Столь устойчивый во времени феномен объясняется, на наш взгляд, следующими обстоятельствами. Река Яма имеет большой мелководный лиман, скатываясь в который молодь проходит период адаптации и этап эстуарного нагула. После выхода из лимана в прибрежье она попадает в район высокой продуктивности кормовых организмов, что обеспечивает ей более благоприятные стартовые условия по сравнению с кетой других популяций. Район прибрежья Ямской губы и Ямских островов является зоной апвеллинга с высокой продуктивностью зоопланктона в теплое время года, биомасса которого достигает 1000 мг/м³ (Маркина, Чернявский, 1984).

Кета ранней формы отличается от поздней не только сроками нерестового хода, но и рядом морфобиологических показателей, в том числе меньшими размерами, массой тела, упитанностью и массой икринок (табл. 5).

В 1936-1939 гг. отмечен пик вылова лососей в Северной Пацифике (Волобуев, Марченко, 2011). Затем в период депрессии 1960-1970-х гг. численность тихоокеанских лососей снизилась более чем в 3 раза по отношению к уровню запасов 1930-х гг. При рассмотрении изменений среднемноголетних показателей длины и массы тела кеты можно отметить их некоторое увеличение в период депрессии в конце 1960-1970-х гг., что, видимо, связано с общим снижением численности азиатских стад лососей и улучшением пищевой обеспеченности в местах основного нагула в океане (Волобуев, Волобуев, 2000; Volobuev, 2000). Очередной подъем численности стад лососей всех стран Тихоокеанского Кольца (Канада, США, Япония, Россия, Республика Корея) произошел в 1980-е гг.

При этом, по отношению к периоду депрессии 1960-1970-х гг., запасы лососей увеличились более чем в 3 раза, что, по-видимому, привело к

Таблица 4. Характеристика основных биологических показателей кеты материкового побережья Охотского моря

Table 4. Characteristics of the main biological parameters of the chum salmon at the continental coast of the Sea of Okhotsk

\begin{tabular}{|c|c|c|c|c|c|c|c|c|c|c|}
\hline \multirow{2}{*}{ Река } & \multicolumn{3}{|c|}{ Длина тела по Смитту, см } & \multicolumn{3}{|c|}{ Масса тела, кг } & \multicolumn{2}{|c|}{ ГСИ, в \% от массы рыбы } & \multirow{2}{*}{ ИАП, икр. } & \multirow{2}{*}{$\begin{array}{c}\mathrm{N}, \\
\text { ЭКЗ. }\end{array}$} \\
\hline & Самцы & Самки & Оба пола & Самцы & Самки & Оба пола & Самцы & Самки & & \\
\hline \multirow{2}{*}{ Гижига } & $\underline{65.7 \pm 0.1}$ & $63.2 \pm 0.1$ & $4.4 \pm 0.1$ & $\underline{3.57 \pm 0.02}$ & $3.06 \pm 0.01$ & $\underline{3.30 \pm 0.01}$ & $\underline{6.36 \pm 0.03}$ & $12.56 \pm 0.05$ & & \multirow{2}{*}{3520} \\
\hline & $49.5-81.0$ & $.5-75.0$ & $.5-81.0$ & $1.33-6.64$ & $1.43-5.76$ & $\overline{1.33-6.64}$ & $2.21-19.17$ & $2.52-20.30$ & 5264 & \\
\hline \multirow{2}{*}{ Наяхан } & $\underline{64.4 \pm 0.1}$ & $\underline{62.3 \pm 0.1}$ & $\underline{63.2 \pm 0.1}$ & $\underline{3.64 \pm 0.02}$ & $3.20 \pm 0.01$ & $\underline{3.40 \pm 0.01}$ & $\underline{6.51 \pm 0.03}$ & $13.32 \pm 0.04$ & & \multirow{2}{*}{5832} \\
\hline & $45.0-86.0$ & $46.0-76.0$ & $45.0-86.0$ & $1.21-8.38$ & $1.52-6.08$ & $1.21-8.38$ & $1.58-15.96$ & $3.09-23.76$ & 5065 & \\
\hline \multirow{2}{*}{ Туманы } & $\underline{64.9 \pm 0.1}$ & $\underline{62.5 \pm 0.1}$ & $\underline{63.8 \pm 0.1}$ & $\underline{3.31 \pm 0.01}$ & & & $\underline{6.22}$ & \pm 0.05 & & \multirow{2}{*}{6507} \\
\hline & $46.0-82.0$ & $43.0-82.0$ & $43.0-82.0$ & $1.50-7.06$ & 1.25 & 1.25 & $\overline{1.15-23.81}$ & $3.94-24.49$ & 332 & \\
\hline \multirow{2}{*}{ Яма } & $\underline{67.1 \pm 0.1}$ & $63.7 \pm 0.1$ & 65. & $4.15 \pm 0.02$ & 3.41 & .01 & $\underline{6.81}$ & 0.05 & & \multirow{2}{*}{6040} \\
\hline & $46.5-82.0$ & $43.5-77.0$ & 43.5 & $1.60-7.90$ & 1.24 & & 1.92 & 5.61 & 555 & \\
\hline \multirow{2}{*}{ Ола } & $\underline{65.0 \pm 0.1}$ & $\underline{61.7 \pm 0.1}$ & $\underline{63.2 \pm 0.1}$ & $\underline{3.48 \pm 0.02}$ & $2.87 \pm 0.01$ & 0.01 & $\underline{6.56}$ & $=0.06$ & 13 & \multirow{2}{*}{3955} \\
\hline & $45.0-80.0$ & $46.0-76.0$ & $45.0-80.0$ & $1.60-6.30$ & & & 0.14 & 5.57 & 161 & \\
\hline \multirow{2}{*}{ Армань } & $\underline{65.7 \pm 0.1}$ & $\underline{62.5 \pm 0.5}$ & $\underline{64.2 \pm 0.3}$ & $\underline{3.86 \pm 0.02}$ & $3.12 \pm 0.02$ & $\underline{3.51 \pm 0.02}$ & $\underline{6.55 \pm 0.27}$ & $=0.07$ & 16 & \multirow{2}{*}{2187} \\
\hline & $45.0-80.0$ & $50.0-71.2$ & & & & & $0.76-11.93$ & .34 & & \\
\hline \multirow{2}{*}{ Яна } & $\underline{66.8 \pm 0.1}$ & $\underline{63.0 \pm 0.1}$ & $\underline{64.9 \pm 0.1}$ & $\underline{3.96 \pm 0.02}$ & $\underline{3.22 \pm 0.01}$ & $\underline{3.57 \pm 0.01}$ & $\underline{6.29 \pm 0.06}$ & $\underline{11.60 \pm 0.05}$ & \pm 12 & \multirow{2}{*}{5697} \\
\hline & $49.0-82.0$ & $46.6-75.5$ & 46.6 & $1.83-7.44$ & 1.51 & $1.51-7.44$ & 0.70 & 21.31 & 863 & \\
\hline \multirow{3}{*}{ Тауй } & $\underline{65.0 \pm 0.1}$ & $\underline{61.2 \pm 0.1}$ & $\underline{63.0 \pm 0.1}$ & $\underline{3.87 \pm 0.01}$ & $\underline{3.12 \pm 0.01}$ & $\underline{3.47 \pm 0.01}$ & $\underline{5.95 \pm 0.02}$ & $\underline{11.52 \pm 0.04}$ & 10 & \multirow{2}{*}{8303} \\
\hline & $49.0-86.0$ & $48.5-74.0$ & $48.5-86.0$ & 1.34 & 1.43 & 0.35 & $1.41-16.64$ & 1.30 & 385 & \\
\hline & $\underline{64.3 \pm 0.2}$ & $\underline{61 . \pm 0.2}$ & $\underline{62.7 \pm 0.1}$ & $\underline{3.95 \pm 0.04}$ & $\underline{3.24 \pm 0.03}$ & $\underline{3.60 \pm 0.03}$ & $\underline{6.55 \pm 0.07}$ & $\underline{11.12 \pm 0.13}$ & & \\
\hline \multirow[t]{2}{*}{ Кухтуй } & $53.6-73.8$ & $53.0-71.8$ & $53.0-73.8$ & $1.92-6.26$ & $1.98-5.33$ & $1.92-6.26$ & $3.66-13.22$ & $5.03-19.26$ & 4700 & \multirow{3}{*}{2293} \\
\hline & $\underline{64.4 \pm 0.2}$ & $\underline{61.3 \pm 0.1}$ & $\underline{62.9 \pm 0.1}$ & $\underline{4.00 \pm 0.03}$ & $\underline{3.29 \pm 0.02}$ & $\underline{3.66 \pm 0.02}$ & $\underline{6.85 \pm 0.06}$ & $\underline{11.24 \pm 0.09}$ & & \\
\hline Охота & $\overline{54.5-73.4}$ & $\overline{52.8-71.6}$ & $\overline{52.8-73.4}$ & $2.03-6.55$ & $\overline{1.91-5.33}$ & $1.91-6.55$ & $3.30-13.22$ & $6.11-18.82$ & $\overline{784-4313}$ & \\
\hline
\end{tabular}

Примечание. Здесь и в табл. 5, 8 над чертой - средняя и ошибка средней, под чертой - колебания признака. 
Таблища 5. Биологические показатели ранней и поздней форм взрослой кеты из приустьевого участка р. Тауй (1992 г.)

Table 5. Biological parameters of early and late forms of the chum salmon adults from the near-mouth part of the Tauy River (1992)

\begin{tabular}{|c|c|c|c|c|c|c|c|c|c|}
\hline \multirow[b]{2}{*}{$\begin{array}{c}\text { Река } \\
\text { (форма) }\end{array}$} & \multirow[b]{2}{*}{$\begin{array}{c}\text { Длина } \\
\text { по Смитту, } \\
\text { см }\end{array}$} & \multirow[b]{2}{*}{$\begin{array}{c}\text { Масса } \\
\text { тела, кг }\end{array}$} & \multirow[b]{2}{*}{ ИАП, икр. } & \multirow[b]{2}{*}{$\begin{array}{c}\text { Масса } \\
\text { одной икр., г }\end{array}$} & \multirow[b]{2}{*}{$\begin{array}{c}\text { Коэф. } \\
\text { упитанности } \\
\text { по Фультону }\end{array}$} & \multicolumn{2}{|c|}{ Коэф. зрелости, \% } & \multirow[b]{2}{*}{$\begin{array}{c}\text { Доля } \\
\text { рыб } \\
\text { возраста } \\
3+, \%\end{array}$} & \multirow[b]{2}{*}{$\begin{array}{l}\mathrm{N}, \\
\text { ЭКз. }\end{array}$} \\
\hline & & & & & & Самцы & Самки & & \\
\hline Тауй & $\underline{60.8 \pm 0.33}$ & $3.31 \pm 0.065$ & $2300 \pm 24.1$ & $\underline{0.160 \pm 0.0014}$ & $\underline{1.43 \pm 0.01}$ & $\underline{6.76 \pm 0.08}$ & $11.39 \pm 0.15$ & & مחת \\
\hline (ранняя) & 5 & $\overline{1.87-6.40}$ & $\overline{1115-3395}$ & $\overline{0.103-0.263}$ & $\overline{1.09-1.93}$ & $\overline{4.11-9.89}$ & $\overline{6.33-15.78}$ & 7. & 200 \\
\hline Тауй & $63.3 \pm 0.23$ & $\underline{3.89 \pm 0.049}$ & $2267 \pm 24.5$ & $\underline{0.170 \pm 0.0021}$ & $\underline{1.51 \pm 0.01}$ & $\underline{6.11 \pm 0.07}$ & $10.85 \pm 0.14$ & & \\
\hline (поздняя) & $53-86$ & $1.71-10.35$ & $\overline{1150-3792}$ & $\overline{0.120-0.280}$ & $\overline{1.10-2.06}$ & $\overline{3.15-11.06}$ & $\overline{6.80-20.23}$ & $5 \% .1$ & 300 \\
\hline
\end{tabular}

изменениям внутривидовой и биологической структуры стад. Так, например, заметно (с 6 до 48-50\%) увеличилась численность кеты ранней формы на североохотоморском побережье (Евзеров, 1983; Волобуев, Голованов, 2001). Произошло увеличение среднего возраста созревания и уменьшение длины, массы тела и плодовитости охотоморской кеты в 1980-1990-е гг., что, очевидно, могло косвенно свидетельствовать о росте напряженности внутри- и межвидовых пищевых отношений лососей в экосистеме северозападной Пацифики (Волобуев, Волобуев, 2000; Volobuev, 2000; Кловач, 2003). Так, масса тела североохотоморской кеты в среднем снизилась на 0.3-0.4 кг, длина - на 3-4 см.

Особенно значительное снижение длины и массы тела кеты, по отношению к среднемноголетним показателям, было отмечено для поколений анадырской кеты 1987-1990-х гг.: в подходах 1992-1994 гг. средняя масса рыб уменьшилась на 0.8-0.9 кг, длина - на 4-5 см. Снижение размеров, массы тела и увеличение возраста созревания анадырской кеты, по мнению некоторых авторов (Чигиринский, 1994; Путивкин, 1999), стало следствием увеличения общей численности лососей в океане на местах основного нагула, в том числе в Беринговом море, за счет роста численности североамериканских и японских стад.

Снижение длины и массы тела отмечено для кеты северо-востока Камчатки на фоне увеличения доли рыб старших возрастных групп, что также связывается с ростом численности искусственно разводимой кеты Японии (Заварина, 2005, 2006).

Установлена плотностно-зависимая связь роста кеты о. Адак (западная группа Алеутских островов), где главным образом распространена кета азиатских стад (Rogers, 1980). Сходная плотностно-зависимая характеристика роста была получена этим автором и для нерки Бристольского залива. Кроме того, Р. М. Петерман (Peterman, 1984) сообщал, что у взрослой нерки в Британской Колумбии и Бристольском заливе установлено значительное снижение размеров тела, когда отмечалось большое количество нерки, нагуливавшейся в зал. Аляска, и он относит это снижение роста на счет пищевой конкуренции.

Известно о влиянии плотностно-зависимых факторов при скате в морское прибрежье многочисленных поколений горбуши (Андриевская, 1998). В этих случаях происходит обострение пищевых межвидовых отношений между горбушей и кетой (Карпенко, 1981, 1983, 1998; Шершнева, Коваль, 2004), когда кета вынужденно переходит на питание второстепенными низкокалорийными объектами, и это отражается на ее темпе роста, скорости созревания и возрасте возврата на нерест. Многочисленные поколения горбуши могут влиять на пищевые отношения с кетой и неркой (Ерохин, 1998).

Существует мнение, что поколения кеты нечетных лет подавляются высокочисленными поколениями горбуши нечетных лет из-за высокой степени пищевого сходства, как это отмечал В. Л. Костарев (1964). Известно, что между кетой и горбушей существует высокое пищевое сходство: СП-коэффициенты достигают 70 90\% (Карпенко, 1998; Ефимкин, 2003; Кловач, 2003; Старовойтов, 2003). Четко обозначенные изменения возраста созревания, длины и массы тела, выживаемости в море и возвратов кеты могут быть обусловлены влиянием параллельных поколений горбуши и действием плотностнозависимых факторов как в пресноводный (конкуренция за места размножения, перекопка нерестовых гнезд, изменение поведенческих реакций и др. (Смирнов, 1947; Ловецкая, 1948; Бирман, 1956; Костарев, 1964; Todd, 1966; Pratt, 1974), так и в морской (пищевая конкуренция) периоды жизни (Андриевская, 1958, 1966; Бирман, 1960; Иванков, Шершнев, 1968; Карпенко, 1998; Коваль, 2009; Karpenko, Koval, 2012; Карпенко и др., 2013). В результате межвидового взаимодействия происходит частичное перекрывание адаптивных зон и конкурентное подавление одного вида (кета) другим (горбуша). Ухудшение биологических показателей кеты в годы высокой численности горбуши можно рассматривать 
как результат действия «принципа конкурентного исключения» Гаузе (Гаузе, 1934; Hardin, 1960; Gallagher, 1979).

Сходные трансформации биологической структуры в этот же период отмечены и для лососей североамериканского и японского происхождения: уменьшение размеров и массы тела и увеличение возраста созревания, которые ряд авторов объясняют плотностно-зависимой связью с ростом (Rogers, 1980; Peterman, 1984, 1991; Kaeriyama, 1989,1996; Ogura et al., 1991; Ishida et al., 1993; Helle, Hoffman, 1995, 1998; Ricker, 1995; Bigler et al., 1996; Helle et al., 2008; Kaeriyama et al., 2008 ).

Вероятно, энергоемкость экосистемы Северной Пацифики в настоящее время обеспечивает близкий к предельно допустимому уровень продукции биомассы лососей. По-видимому, дальнейшее искусственное наращивание численности тихоокеанских лососей может привести к еще большим изменениям биологической структуры стад, ухудшению их качественных характеристик, снижению товарной ценности уловов.

По-видимому, продукция биомассы лососей, которая обеспечивается возможностями экосистемы Северной Пацифики в этих условиях, попадает под определение «максимальной поддерживающей емкости среды» (Одум, 1986). В настоящее время в развитии экосистемы Северной Пацифики мы наблюдаем значительное аллогенное влияние, обусловленное антропогенным вмешательством. Взаимодействие ауто- и аллогенных факторов (взаимовлияние природных и искусственно созданных стад лососей), вероятно, оказало воздействие на траекторию развития сукцессии северотихоокеанской экосистемы, что находит отражение в изменении биологической структуры стад азиатских и североамериканских лососей.

В целом приведенные оценки параметров биологических показателей охотоморской кеты не выходят за характерные для вида пределы. Отмечена мозаичность в изменчивости качественных показателей кеты, отсутствие выраженной клины, что, возможно, является результатом анализа частично смешанных выборок двух сезонных форм.
Соотношение полов. Соотношение полов у североохотоморской кеты варьирует в различных возрастных группах. У молодых рыб в возрасте $2+$, как правило, преобладают самцы, у 4-леток самки (табл. 6). В среднем по всем возрастным группам соотношение полов близко к равному или чуть выше доля самок - 50.1-52.8\%. Соотношение полов меняется в течение анадромной миграции. В начале нерестового хода преобладают самцы - до 65-70\%, к середине его соотношение самцов и самок выравнивается, а к концу миграции начинают доминировать самки - до 60-65\%.

Плодовитость. Абсолютная плодовитость североохотоморской кеты коррелирует с длиной тела (Клоков, 1975). Пределы варьирования плодовитости кеты основных популяций составили 300-10332 икр., средние величины были в пределах 2502-2914 икр. (см. табл. 4). Наибольшей плодовитостью характеризуется кета р. Яма, что обусловлено ее большими размерно-весовыми показателями.

Кета ранней формы имеет большую плодовитость по сравнению с одноразмерными особями поздней кеты, что обусловлено меньшими размерами икринок (см. табл. 5) (Медников и др., 1988; Волобуев и др., 1990). Размер икринок зависит от стадии их развития. Показано, что кета, размножающаяся в реках большей протяженности, имеет в устье менее зрелую, более мелкую икру, и, наоборот, в малые реки она подходит с более крупной зрелой икрой. При сравнении размерновесовых характеристик, упитанности, массы икринок кеты ранней и поздней форм из приустьевых участков р. Тауй (см. табл. 5) и с нерестилищ этой же реки (табл. 7) отмечены их более низкие показатели у ранней формы кеты. Средняя масса икринок увеличивалась за время нерестовой миграции: у ранней формы - на 20\%, у поздней - на $27 \%$.

В настоящее время абсолютная плодовитость североохотоморской поздней кеты близка к таковой 1970-х гг. (Клоков, 1975), а плодовитость ранней формы сходна с плодовитостью летней амурской и западнокамчатской кеты (Николаева, 1974; Платошина, 1984). Наибольшая среднемноголетняя величина абсолютной плодовитости

\section{Таблииа 6. Доля самок в подходах кеты материкового побережья Охотского моря, \%}

Table 6. Female share in the returns of the chum salmon at the continental coast of the Sea of Okhotsk, \%

\begin{tabular}{|c|c|c|c|c|c|c|c|}
\hline \multirow{2}{*}{ Стадо (река) } & \multicolumn{6}{|c|}{ Возраст, лет } & \multirow{2}{*}{ Средняя } \\
\hline & $1+$ & $2+$ & $3+$ & $4+$ & $5+$ & $6+$ & \\
\hline $\begin{array}{l}\text { Гижигинское } \\
\text { (Гижига) }\end{array}$ & - & 11.3 & 53.1 & 45.6 & 46.6 & 100 & 52.8 \\
\hline Ямское (Яма) & - & 28.4 & 49.7 & 51.0 & 51.8 & 61.5 & 50.1 \\
\hline Тауйское (Тауй) & 100 & 43.3 & 54.0 & 52.1 & 49.3 & 45.5 & 52.3 \\
\hline Охотское (Кухтуй) & - & 53.3 & 52.2 & 49.7 & 41.4 & 83.0 & 50.1 \\
\hline
\end{tabular}


Таблица 7. Некоторые биологические показатели кеты ранней и поздней форм из района нерестилищ в бассейне р. Тауй

Table 7. Some biological parameters of the chum salmon of early and late forms from spawning grounds in the Tauy River basin

\begin{tabular}{|c|c|c|c|c|c|c|c|c|}
\hline \multirow{2}{*}{ Река } & \multirow{2}{*}{ Длина, см } & \multirow{2}{*}{$\begin{array}{c}\text { Масса } \\
\text { тела, кг }\end{array}$} & \multirow{2}{*}{$\begin{array}{c}\text { Коэф-т } \\
\text { упитанности }\end{array}$} & \multicolumn{2}{|c|}{ Коэф-т зрелости } & \multirow{2}{*}{ ИАП, икр. } & \multirow{2}{*}{$\begin{array}{c}\text { Масса одной } \\
\text { икр., г }\end{array}$} & \multirow{2}{*}{$\begin{array}{l}\mathrm{N}, \\
\text { ЭКз. }\end{array}$} \\
\hline & & & & Самцы & Самки & & & \\
\hline $\begin{array}{l}\text { Чукчинка } \\
\text { (приток р. Ка- }\end{array}$ & $\underline{59.9 \pm 0.41}$ & $2.78 \pm 0.088$ & $\underline{3.29 \pm 0.050}$ & $\underline{3.62 \pm 0.53}$ & $20.96 \pm 0.25$ & $\underline{2589 \pm 67}$ & $\underline{0.192 \pm 0.0085}$ & \\
\hline $\begin{array}{l}\text { ва), ранняя } \\
\text { форма }\end{array}$ & $55-71$ & $1.67-5.06$ & $2.45-4.16$ & $3.40-4.03$ & $\overline{16.41-24.52}$ & $1344-4030$ & $0.134-0.253$ & 67 \\
\hline Чёломджа, & $\underline{63.2+0.52}$ & $\underline{3.58 \pm 0.70}$ & $\underline{3.62 \pm 0.048}$ & $\underline{4.01 \pm 0.63}$ & $\underline{15.93 \pm 0.43}$ & $\underline{2997 \pm 40}$ & $\underline{0.216 \pm 0.0019}$ & \\
\hline $\begin{array}{l}\text { поздняя } \\
\text { форма }\end{array}$ & $57-75$ & $1.66-6.31$ & $2.41-5.00$ & $2.37-7.11$ & $\overline{13.32-22.49}$ & $1838-4464$ & $0.164-0.263$ & 129 \\
\hline
\end{tabular}

Примечание. Над чертой - среднее значение признака и ошибка средней, под чертой - его колебания. В связи с высокой степенью выраженности брачного наряда для определения коэффициента упитанности брали длину тушки (ОД).

отмечена у кеты р. Яма - 2914 икр., затем идет кета рр. Туманы, Охота, Гижига (см. табл. 4). При рассмотрении среднемноголетних показателей плодовитости североохотоморской кеты в ряду рр. Гижига - Кухтуй (с северо-востока на юго-запад) можно отметить, что в целом у кеты северо-восточных популяций она выше. Сходная закономерность наблюдается у симы и камчатской кеты (Иванков, 1968; Николаева, 1974).

Упитанность, зрелость. Средний коэффициент упитанности кеты всех популяций снижается от начала к концу нерестового хода с 1.80-1.42 до 1.66-1.30, что, видимо, объясняется увеличением доли самок и самцов младших возрастных групп к концу нерестовой миграции.

В течение сезона коэффициент упитанности колебался от 0.75 до 3.20 (табл. 8). Максимальной упитанностью выделяется поздняя кета рр. Яма, Тауй, Кухтуй. Обычно упитанность самцов выше. В устье рек разница в коэффициентах упитанности между самцами и самками составляет $0.12-0.18 \%$, на нерестилищах эти разли- чия возрастают в 4-5 раз - до 0.6-0.8\%. Упитанность североохотоморской кеты близка к таковой восточно-камчатской (Николаева, 1974) и согласуется с данными В. Л. Костарева (1967) для кеты Охотского района Хабаровского края. Кета ранней и поздней форм различается по упитанности как в устьях рек, так и в период нереста: упитанность поздней кеты выше (см. табл. 7).

Среднемноголетние значения коэффициента зрелости кеты исследованных популяций у самцов в приустьевых участках нерестовых рек варьировали от 7.07 до 8.04 , у самок - от 12.64 до $17.12 \%$, размах индивидуальных значений гораздо шире (см. табл. 8). На нерестилищах коэффициент зрелости самцов ранней кеты снижается до 3.62, поздней - до 4.01\% вследствие превращения генеративной ткани семенников в половые продукты, а коэффициент зрелости самок возрастает в среднем до 16-21\% из-за увеличения размера и массы икринок и массы гонад (см. табл. 7). Масса гонад отдельных самок на нерестилищах достигает 1200 г.

Таблица 8. Упитанность и степень зрелости гонад кеты материкового побережья Охотского моря Table 8. Fatness and maturity of gonads of the chum salmon at the continental coast of the Sea of Okhotsk

\begin{tabular}{|c|c|c|c|c|}
\hline \multirow{2}{*}{ Река } & \multicolumn{2}{|c|}{ Коэффициент зрелости, \% } & \multicolumn{2}{|c|}{ Коэффициент упитанности } \\
\hline & Самцы & Самки & Самцы & Самки \\
\hline Наяуоч & $7.43 \pm 0.08$ & $16.69 \pm 0.15$ & $1.41 \pm 0.01$ & $1.26 \pm 0.01$ \\
\hline Паяхан & $2.96-13.91$ & $6.28-29.01$ & $1.05-1.74$ & $0.92-1.90$ \\
\hline$g_{M a}$ & $\underline{8.04 \pm 0.08}$ & $\underline{17.12 \pm 0.17}$ & $1.46 \pm 0.01$ & $1.29 \pm 0.01$ \\
\hline яма & $4.17-16.93$ & $8.90-30.92$ & $0.84-1.80$ & $0.75-1.55$ \\
\hline & $\underline{7.52 \pm 0.13}$ & $\underline{15.19 \pm 0.20}$ & $\underline{1.28 \pm 0.01}$ & $\underline{1.16 \pm 0.01}$ \\
\hline Ола & $2.24-13.73$ & $\overline{5.01-27.44}$ & $\overline{0.97-2.08}$ & $\overline{0.83-1.64}$ \\
\hline Яна & $\underline{7.78 \pm 0.10}$ & $\underline{12.64 \pm 0.17}$ & $\underline{1.40 \pm 0.01}$ & $\underline{1.28 \pm 0.01}$ \\
\hline Лна & $2.40-14.39$ & $6.86-20.75$ & $1.09-2.43$ & $1.00-1.59$ \\
\hline Тәуй & $\underline{7.07 \pm 0.07}$ & $\underline{13.47 \pm 0.13}$ & $1.45 \pm 0.02$ & $\underline{1.27 \pm 0.02}$ \\
\hline 1ауи & $2.54-21.82$ & $2.37-30.00$ & $1.06-3.20$ & $0.86-2.88$ \\
\hline КУхтуй & $\underline{7.56 \pm 0.09}$ & $\underline{13.68 \pm 0.17}$ & $\underline{1.55 \pm 0.01}$ & $\underline{1.40 \pm 0.01}$ \\
\hline Кухтуи & $4.00-15.80$ & $5.56-26.00$ & $1.25-1.87$ & $0.95-1.91$ \\
\hline
\end{tabular}




\section{ЗАКЛЮЧЕНИЕ}

По своим биологическим параметрам ранняя и поздняя формы североохотоморской кеты не имеют больших отличий от кеты соответствующих форм Камчатки или Сахалина. Биологическая структура взрослых лососей является одним из основных критериев оценки состояния стад, а ее показатели часто используются в качестве прогнозных предикторов для оценки подходов. Средний возраст североохотоморской кеты по годам наблюдений варьирует от 3.15 до 4.00 лет, в подходах присутствуют рыбы от 1+ до 6+ лет, доминируют рыбы возраста $3+$ и 4+ лет. Размерный и весовой ряды североохотоморской кеты довольно широки: длина взрослых рыб колеблется от 43 до 86 см, масса тела - от 1.21 до 10.35 кг. По среднемноголетним показателям длины и массы тела более крупной является кета р. Яма. Ранняя кета от поздней отличается меньшими размерами, массой тела, упитанностью и массой икринок. У североохотоморской кеты отмечены периодические изменения основных биологических характеристик, сопряженных с ее численностью: в годы роста запасов происходит увеличение возраста созревания и снижение размерно-весовых показателей, в периоды снижения численности наблюдается обратный процесс в динамике ее основных биологических параметров. В целом анализ основных показателей биологической структуры охотоморской кеты показал, что они не выходят за пределы характерных видоспецифических признаков.

\section{ЛИТЕРАТУРА}

Андриевская Л. Д. Питание тихоокеанских лососей в северо-западной части Тихого океана // Материалы по биологии морского периода жизни лососей. М. : ВНИРО, 1958. С. 64-75.

Андриевская Л. Д. Пищевые взаимоотношения тихоокеанских лососей в море // Вопр. ихтиологии. 1966. Вып. 6. С. 84-90.

Андриевская Л. Д. Условия формирования продукции поколений горбуши Oncorhynchus gorbuscha (Walbaum) (Salmonidae) в юго-западной части Берингова моря // Сб. науч. тр. КамчатНИРО. 1998. Вып. 4. C. 94-97.

Андрияшев А. П. Рыбы северных морей СССР. М. ; Л. : Изд-во АН СССР, 1954. 566 с.

Берг Л. С. Рыбы пресных вод СССР и сопредельных стран. М. ; Л. : Изд-во АН СССР, 1948. Ч. 1. 466 с.

Бирман И. Б. Локальные стада осенней кеты в бассейне Амура // Вопр. ихтиологии. 1956. Вып. 7. C. 158-173.

Бирман И. Б. Новые данные о морском периоде жизни и морском промысле тихоокеанских лососей // Тр. совещ. ихтиол. комиссии АН СССР. 1960. Вып. 10. C. $151-164$.

Бирман И. Б. Приспособительные особенности нерестовой миграции амурской кеты // Изв. ТИНРО. 1952. T. 37. C. 109-137.

Бугаев А. В., Заволокина Е. А., Заволокин А. В. и $\partial p$. Происхождение и распределение локальных стад кеты Oncorhynchus keta в западной части Берингова моря по данным траловых съемок НИС «ТИНРО» в 2004 и 2006 гг. // Изв. ТИНРО. 2009. Т. 157. С. 3-33.

Волобуев В. В., Голованов И. С. Запасы тихоокеанских лососей Магаданской области // Сб. науч. тр. МагаданНИРО. 2001. Вып. 1. С.123-133.

Волобуев В. В., Рогатных А. Ю., Кузищин К. В., Царев Ю. И. Морфологическая дифференциация ранней и поздней кеты Oncorhynchus keta (Walb.) p. Taуй // Популяционная биология лососей Северо-Востока Азии. Владивосток : ДВО АН СССР, 1992. С. 72-80.

Волобуев В. В. О внутривидовой дифференциации кеты р. Тауй (Североохотоморское побережье) : тез. докл. 10-го Всесоюз. симп. «Биологические проблемы Севера». Магадан, 1983. Ч. 2. С. 155-156.

Волобуев В. В. О внутривидовой неоднородности кеты Oncorhynchus keta (Walbaum) материкового побережья Охотского моря : тез. докл. 11-го Всесоюз. симп. «Биологические проблемы Севера». Якутск, 1986. Вып. 4. С. 22-23.

Волобуев В. В., Рогатных А. Ю., Кузищчин К. В. О внутривидовых формах кеты Oncorhynchus keta материкового побережья Охотского моря // Вопр. ихтиологии. 1990. Т. 30. Вып. 2. С. 221-228.

Волобуев В. В. Об особенностях размножения кеты Oncorhynchus keta (Walbaum) (Salmonidae) и экологии ее молоди в бассейне р. Тауй // Там же. 1984. Т. 24. Вып. 6. С. 953-963.

Волобуев В. В., Бачевская Л. Т., Волобуев М. В., Марченко C. Л. Популяционная структура кеты Oncorhynchus keta (Walbaum) континентального побережья Охотского моря // Там же. 2005. Т. 45, № 4. С. 489501.

Волобуев В. В., Марченко С. Л. Тихоокеанские лососи континентального побережья Охотского моря. Магадан : МагаданНИРО, 2011. 303 с.

Волобуев В. В., Рогатных А. Ю. Условия воспроизводства лососей рода Oncorhynchus материкового побережья Охотского моря // Вопр. ихтиологии. 1997. T. 37, № 5. C. 612-618.

Волобуев В. В., Волобуев М. В. Экология и структура популяций как основные элементы формирования жизненной стратегии кеты Oncorhynchus keta континентального побережья Охотского моря // Там же. 2000. T. 40, № 4. C. 510-529.

Гаузе $Г$. Ф. Экспериментальное исследование борьбы за существование между Paramecium aurelia и Stylonychia mytilus // Зоол. журнал. 1934. Т. 13. Вып. 1. C. 1-17.

Евзеров А. В. Нерестовый фонд охотоморской и анадырской кеты // Биол. основы развития лососевого хоз-ва в водоемах СССР. М. : Наука, 1983. С. 103-113.

Ерохин В. Г. Распределение и биологические показатели молоди нерки Oncorhynchus nerka (Walbaum) (Salmonidae) в восточной части Охотского моря // Сб. науч. тр. КамчатНИРО. 1998. Вып. 4. С. 124-130.

Ефимкин А. Я. Питание лососей в западной части Берингова моря в летне-осенний период 2002 г. // Изв. ТИНРО. 2003. Т. 134. С. 120-134.

Заварина Л. О. Об изменении биологических показателей кеты (Oncorhynchus keta) на северо-восточном побережье Камчатки // Тр. ВНИРО. 2006. Т. 146. C. 211-226.

Заварина Л. О. Тенденции изменения численности кеты Северо-Востока Камчатки и динамика ее биологических показателей : Материалы VI науч. конф. (Петропавловск-Камчатский. 29-30 ноября 2005 г.). П.-Камчатский : Камчатпресс, 2005. С. 44-47. 
Иванков В. Н., Шершнев А. П. Биология молоди горбуши и кеты в море // Рыб. хоз-во. 1968. № 4. C. $16-17$.

Иванков В. Н. Тихоокеанские лососи острова Итуруп (Курильские острова) // Изв. ТИНРО. 1968. Т. 65. C. 49-74.

Иванков В. Н. Изменчивость и внутривидовая дифференциация кеты // Гидробиол. журнал. 1970. Т. 6, № 2. C. 106-112.

Карпенко В. И. Влияние факторов среды на формирование качественных показателей молоди дальневосточных лососей рода Oncorhynchus (Salmonidae) в прикамчатских водах Берингова моря // Вопр. ихтиологии. 1983. Т. 23. Вып. 5. С. 813-820.

Карпенко В. И. Кормовая база и питание молоди горбуши (Oncorhynchus gorbuscha Walbaum) и кеты (Oncorhynchus keta Walbaum) в прибрежных водах Карагинского залива Берингова моря // Там же. 1981. T. 21. Вып . 4. С. 675-685.

Карпенко В. И., Андриевская Л. Д., Коваль М. В. Питание и особенности роста тихоокеанских лососей в морских водах. П.-Камчатский : КамчатНИРО, 2013. 304 с.

Карпенко В. И. Ранний морской период жизни тихоокеанских лососей. М. : ВНИРО, 1998. 165 с.

Кловач Н. В. Экологические последствия крупномасштабного разведения кеты. М. : ВНИРО, 2003. 164 с.

Клоков В. К. Изменчивость размерно-весовых показателей кеты северного побережья Охотского моря // Изв. ТИНРО. 1973. Т. 86. С. 81-100.

Клоков В. К. К вопросу о динамике численности нерестовых стад лососей на Северном побережье Охотского моря // Изв. ТИНРО. 1970. Т. 71. С. 169-177.

Клоков В. К. Популяционная структура и динамика численности кеты северного побережья Охотского моря : автореф. дис. ... канд. биол. наук. Владивосток, 1975. $27 \mathrm{c}$

Коваль М. В. Особенности нагула и преднерестовых миграций тихоокеанских лососей в прикамчатских водах летом 2009 г. // Бюл. № 4 реализации «Концепции дальневосточной бассейновой программы изучения тихоокеанских лососей». Владивосток : ТИНРО-центр, 2009. С. 150-158.

Костарев В. Л. Возраст и рост охотской кеты // Изв. ТИНРО. 1967. Т. 61. С. 173-181.

Костарев В. Л. Некоторые закономерности колебаний численности охотских лососей // Лососевое хозяйство Дальнего Востока. М. : Наука, 1964. C. $77-83$.

Костарев В. Л. Промысел охотской кеты // Изв. ТИНРО. 1970. Т. 71. С. 133-143.

Кузишин К. В., Груздева М. А., Савваитова К. А. и $\partial p$. Сезонные расы кеты Oncorhynchus keta и их взаимоотношения в реках Камчатки // Вопр. ихтиологии. 2010. T. 50, № 2. C. 202-215.

Куликова Н. И. Изменчивость и пути формообразования у кеты Oncorhynchus keta (Walb.) // Там же. 1972. т. 12. Вып. 2 (73). С. 211-225.

Кульбачный C. Е., Иванков В. Н. Темпоральная дифференциация и условия размножения кеты Oncorhynchus keta (Salmoniformes: Salmonidae) бacсейна реки Тугур (Хабаровский край) // Там же. 2011. T. 51, № 1. C. 70-79.

Леванидов В. Я. Воспроизводство амурских лососей и кормовая база их молоди в притоках Амура // Изв. ТИНРО. 1969. Т. 67. 242 с.

Ловеикая E. А. Материалы по биологии амурской кеты // Там же. 1948. Т. 27. С. 115-137.
Лососи-2000. Путинный прогноз. Владивосток : ТИНРО-Центр, 2000. 86 с.

Лососи-2001. Путинный прогноз. Владивосток : ТИНРО-Центр, 2001. 89 с.

Лососи-2002. Путинный прогноз. Владивосток : ТИНРО-Центр, 2002. 88 с.

Лососи-2003. Путинный прогноз. Владивосток : ТИНРО-Центр, 2003. 100 с.

Лососи-2004. Путинный прогноз. Владивосток : ТИНРО-Центр, 2004. 112 с.

Лососи-2005. Путинный прогноз. Владивосток :

ТИНРО-Центр, 2005. 95 с.

Лососи-2006. Путинный прогноз. Владивосток :

ТИНРО-Центр, 2006. 112 с

Лососи-2007. Путинный прогноз. Владивосток : ТИНРО-Центр, 2007. 131 с.

Лососи-2008. Путинный прогноз. Владивосток :

ТИНРО-Центр, 2008. 118 с.

Лососи-2009. Путинный прогноз. Владивосток :

ТИНРО-Центр, 2009. 114 с.

Лососи-2010. Путинный прогноз. Владивосток :

ТИНРО-Центр, 2010. 126 с.

Лососи-2011. Путинный прогноз. Владивосток :

ТИНРО-Центр, 2011. 125 с.

Лососи-2012. Путинный прогноз. Владивосток :

ТИНРО-Центр, 2012. 129 с.

Лососи-2013. Путинный прогноз. Владивосток :

ТИНРО-Центр, 2013. 126 с.

Лососи-2014. Путинный прогноз. Владивосток : ТИНРО-Центр, 2014. 121 с.

Маркина Н. П., Чернявский В. И. Количественное распределение планктона и бентоса в Охотском моpe // Изв. ТИНРО. 1984. Т. 109. С. 109-119.

Медников Б. М., Волобуев В. В., Горшков В. А. и др. Структура нерестовой популяции кеты Oncorhynchus keta бассейна реки Тауй (по данным молекулярной гибридизации ДНК) // Вопр. ихтиологии. 1988. Т. 28. Вып. 5. С. 724-731.

Николаева Е. Т., Заварина Л. О., Николаева А. А. Морфологическое описание «весенней» и «летней» кеты Oncorhynchus keta p. Камчатка (Камчатка) // Сб. науч. тр. КамчатНИРО. 1995. Вып. 3. С. 125-129.

Николаева Е. Т., Овчинников К. А. О внутривидовой структуре кеты Oncorhynchus keta на Камчатке // Вопр. ихтиологии. 1988. Т. 28. Вып. 3. С. 493-496.

Николаева E. T. О плодовитости камчатской кеты // Изв. ТИНРО. 1974. Т. 90. С. 145-172.

Одум Ю. Экология. М. : Мир, 1986. Т. 2. 376 с.

Платошина Л. К. Биологические показатели летней кеты из разных рек бассейна Амура // Биология проходных рыб Дальнего Востока. Владивосток : ДВГУ, 1984. С. 57-64.

Правдин И. Ф. Обзор исследований дальневосточных лососей // Изв. ТИНРО. 1940. Т. 18. 107 с.

Правдин И. Ф. Руководство по изучению рыб. М. : Пищ. пром-сть, 1966. 376 с.

Путивкин С. В. Биология и динамика численности анадырской кеты : автореф. дис. ... канд. биол. наук. Владивосток, 1999. $24 \mathrm{c}$.

Путивкин C. В. О формировании гидрологического режима нерестилищ анадырской кеты // Вопр. ихтиологии. 1989. Т. 29. Вып. 1. С. 96-103.

Смирнов А. Г. Состояние запасов амурских лососей и причины их численных колебаний // Изв. ТИНPO. 1947. Т. 25. С. 33-51.

Смирнов А. И. Биология, размножение и развитие тихоокеанских лососей. М. : Изд-во МГУ, 1975. 334 с. 
Старовойтов A. H. Кета (Oncorhynchus keta (Walbaum)) в дальневосточных морях - биологическая характеристика вида. 1. Сезонное распределение и миграции кеты в дальневосточных морях и открытых водах северо-западной Пацифики // Изв. ТИНРО. 2003. T. 132. C. 43-81.

Черешнев И. А. К систематике кеты Oncorhynchus keta (Walbaum) Чукотского полуострова // Фауна пресных вод Дальнего Востока. Владивосток : ДВНЦ АН CCCP, 1980. С. 113-135.

Черешнев И. А. Материалы по биологии проходных лососевых Восточной Чукотки // Рыбы в экосистемах лососевых рек Дальнего Востока. Владивосток : ДВНЦ АН СССР, 1981. С. 116-146.

Чигиринский А. И. Промысел тихоокеанских лососей в Беринговом море // Изв. ТИНРО. 1994. Т. 116. C. $142-152$.

Шершнева В. И., Коваль М. В. Калорийность массовых видов зоопланктона и ихтиопланктона прикамчатских вод // Там же. 2004. Т. 139. С. 349-369.

Bigler B. S., Welch D. W., Helle J. H. A review of size trends among North Pacific Salmon (Oncorhynchus spp.) // Can. J. Fish. Aquat. Sci. 1996. Vol. 53. P. 455-465.

Gallagher A.F. An analysis of factors affecting brood year returns in the wild stock of Puget Sound chum (Oncorhynchus keta) and pink salmon (Oncorhynchus gorbuscha) : M. Sci. thesis. Seattle: Univ. of Washington, 1979. $152 \mathrm{p}$.

Hardin $G$. The competitive exclusion principle // Science. 1960. Vol. 131. P. 1292-1297.

Helle J. H., Hoffman M. S. Changes in size and age at maturity of two North American stocks of regime shift in the North Pacific Ocean // Assessment and status Pacific Rim salmonid stocks. Bull. NPAFC. 1998. No. 1. P. 81-89.

Helle J. H., Martinson E. C., Fukuwaka M. Is body size of maturing chum salmon returning to North America and Japan related to population density and/or sea conditions in the Eastern Bering Sea? // BASIS Symposium. 2008. P. 37.

Helle J. H., Hoffman M. S. Size decline and older age at maturity of two chum salmon (Oncorhynchus keta) stocks in western America, 1972-92. Climate change and northern fish populations // Can. Spec. Publ. Fish. Aquat. Sci. 1995. Vol. 121. P. 245-260.
Ishida Y., Ito S., Kaeriyama M., McKinnel S., Nagasava $K$. Recent changes in age and size of chum salmon (Oncorhynchus keta) in the North Pacific Ocean and possible causes // Can. J. Fish. Aquat. Sci. 1993. Vol. 50. P. 290-295.

Kaeriyama M. Aspects of salmon ranching in Japan // Physiol. Ecol. Jpn. Spec. 1989. Vol. 1. P. 625-638.

Kaeriyama M. Changes in Body Size and Age at Mature of a Chum Salmon Oncorhynchus keta population released from Hokkaido in Japan // Doc. NPAFC. 1996. 208. 9 p.

Kaeriyama M., Seo H., Urawa S. Perspective on production trends and Carrying Capacity of Pacific salmon in the North Pacific // BASIS Symposium. 2008. 33 p.

Karpenko V. I., Koval M. V. Feeding strategies and trends of pink and chum salmon growth in the marine Kamchatka waters // NPAFC Technical Rep. No. 8. 2012. Vancouver. Canada. P. 82-86.

Ogura M., Ishida Y., Ito $S$. Growth variation of coho salmon Oncorhynchus kisutch in the western North Pacific // Nippon Suisan Gakkaishi. 1991. Vol. 57. P. 1089-1093.

Peterman R. M. Density-dependent growth in early ocean life of sockeye salmon (Oncorhynchus nerka) // Can. J. Fish. Aquat. Sci. 1984. Vol. 41. P. 1825-1829.

Peterman R. M. Density-dependent marine processes in North Pacific salmonids: lessons for experimental design of large-scale manipulations of fish stocks // ICES Mar. Sci. Symp. 1991. Vol. 192. P. 69-77.

Pratt D. C. Age, sex, length, weight, and scarring of adult chum salmon (Oncorhynchus keta) harvested by Puget Sound commercial net fisheries from 1954 to 1970: supplemental progress report // Mar. Fish. Invest. Olympia. Wash. Dep. Fish and Wildlife. 1974. 78 p.

Ricker $W$. E. Trends in the average size of Pacific salmon in Canadian catches // Can. Spec. Publ. Fish. Aquat. Sci. 1995. Vol. 121. P. 593-602.

Rogers D. E. Density-dependent growth of Bristol Bay sockeye salmon // Salmonid Ecosystems of the North Pacific / ed. W. J. McNeil, D. C. Himsworth. Oregon State University Press, 1980. Corvallis. OR. P. 267-283.

Todd I. S. A technique for the enumeration of chum salmon fry in the Fraser River, British Columbia // Can. Fish. Cult. 1966. Vol. 38. P. 3-35.

Volobuev $V$. $V$. Long-term changes in the biological parameters of chum salmon of the Okhotsk Sea // Bull. NPAFC. 2000. No. 2. P. 175-180.

Поступила в редакцию 13.08.2018 2.

Поступила после доработки 26.12.2018 2.

\title{
BIOLOGICAL STRUCTURE OF THE CHUM SALMON ONCORHYNCHUS KETA AT THE CONTINENTAL COAST OF THE SEA OF OKHOTSK
}

\author{
V. V. Volobuev, V. A. Grushinets
}

\author{
Magadan Research Institute of Fisheries and Oceanography, Magadan
}

The biological structure of chum salmon adults, both in the mixed samples and separately for two ecological forms (early and late) in the rivers of the continental coast of the Sea of Okhotsk is considered. Data on their age, size-weight structure, sex ratio, fatness, degree of maturity of sexual products are presented. Influence of some biocenotic factors on the chum salmon biological structure is considered.

Keywords: chum salmon, age structure, size, body weight, fatness, maturity. 


\section{REFERENCE}

Andriyevskaya, L. D., 1958, Nutrition of the Pacific Salmon in the North-Western Pacific, Materials on the Biology of the Marine Life of Salmon, Moscow, VNIRO, 6475 [In Russian].

Andriyevskaya, L. D., 1966, Food Relationships of the Pacific Salmon in the Sea, Jounal of Ichthyology, Iss. 6, 84-90 [In Russian].

Andrievskaya, L. D., 1998, Conditions for the Formation of Pink Salmon Oncorhynchus gorbuscha (Walbaum) (Salmonidae) Generations Production in the South-Western Part of the Bering Sea, Sbornik Nauchnykh Trudov KamchatNIRO, Iss. 4, 94-97 [In Russian].

Andriyashev, A. P., 1954, Fish of the Northern Seas of the USSR, Moscow - Leningrad, Izd-vo AN SSSR [In Russian].

Berg, L. S., 1948, Freshwater Fish of the USSR and Neighboring Countries, Moscow, Leningrad, Izd-vo AN SSSR, Part 1 [In Russian].

Bigler, B. S.; Welch, D. W.; Helle, J. H., 1996, A Review of Size Trends among North Pacific Salmon (Oncorhynchus spp.), Can. J. Fish. Aquat. Sci., 53, 455-465.

Birman, I. B., 1952, Adaptive Features of the Spawning Migration of Amur River Chum Salmon, Izvestiya TINRO, Iss. 37, 109-137 [In Russian].

Birman, I. B., 1956, Local Stocks of the Autumn Chum Salmon in the Amur River Basin, Journal of Ichthyology, Iss. 7, 158-173 [In Russian].

Birman, I. B., 1960, New Data on the Marine Period of Life and Marine Fishery of Pacific Salmon, Trudy Soveshchaniya Ichtiologicheskoy Komissii AN SSSR, Iss. 10, 151-164 [In Russian].

Bugayev, A. V.; Zavolokina, E. A.; Zavolokin, A. V.; Zavarina, L. O.; Kireyev, I. N.; Shubin, A. O.; Ignatyev, Yu. I.; Zolotukhin, S. F.; Kaplanova, N. F.; Volobuev, M. V., 2009, Origin and Distribution of Local Stocks of the Chum Salmon Oncorhynchus keta in the Western Part of the Bering Sea by the Trawl Surveys of the R/V TINRO in 2004 and 2006, Izvestiya TINRO, 157, 3-33 [In Russian].

Chereshnev, I. A., 1980, On the Systematics of the Chum Salmon Oncorhynchus keta (Walbaum) of the Chukotka Peninsula, Fauna of Fresh Waters of the Far East, Vladivostok, DVNC AN SSSR, 113-135 [In Russian].

Chereshnev, I. A., 1981, Materials on the Biology of Anadromous Salmon of Eastern Chukotka, Fishes in the Ecosystems of the Salmon Rivers of the Far East, Vladivostok, DVNC AN SSSR, 116-146 [In Russian].

Chigirinsky, A.I., 1994, Pacific Salmon Fishing in the Bering Sea, Izvestiya TINRO, 116, 142-152 [In Russian]. Gallagher, A. F., 1979, An Analysis of Factors Affecting Brood Year Returns in the Wild Stock of Puget Sound Chum (Oncorhynchus keta) and Pink Salmon (Oncorhynchus gorbuscha), M. Sci. Thesis, Seattle, Univ. of Washington.

Gause, G. F., 1934, Experimental Study of the Struggle for Existence Between Paramecium aurelia and Stylonychia mytilus, Zoologicheskiy Zhurnal, 13, Iss. 1, 1-17 [In Russian].

Hardin, G., 1960, The Competitive Exclusion Principle, Science, 131, 1292-1297.

Helle, J. H.; Hoffman, M. S., 1995, Size Decline and Older Age at Maturity of Two Chum Salmon (Onco- rhynchus keta) Stocks in Western America, 1972-92, Climate Change and Northern Fish Populations, Can. Spec. Publ. Fish. Aquat. Sci., 121, 245-260.

Helle, J. H.; Hoffman, M. S., 1998, Changes in Size and Age at Maturity of Two North American Stocks of Regime Shift in the North Pacific Ocean, Assessment and Status Pacific Rim Salmonid Stocks, Bull. NPAFC, 1, 8189.

Helle, J. H.; Martinson, E. C.; Fukuwaka, M., 2008, Is Body Size of Maturing Chum Salmon Returning to North America and Japan Related to Population Density and/or Sea Conditions in the Eastern Bering Sea?, BASIS Symposium, 37.

Ishida, Y.; Ito, S.; Kaeriyama, M.; McKinnel, S.; Nagasava, K., 1993, Recent Changes in Age and Size of Chum Salmon (Oncorhynchus keta) in the North Pacific Ocean and Possible Causes, Can. J. Fish. Aquat. Sci., 50, 290-295.

Ivankov, $V . N ., 1968$, Pacific Salmon of the Iturup Island (Kuril Islands), Izvestiya TINRO, 65, 49-74 [In Russian].

Ivankov, V.N., 1970, Variability and Intraspecific Differentiation of the Chum Salmon, Gidrobiologicheskiy Zhurnal, 6, 2, 106-112 [In Russian].

Ivankov, V. N.; Shershnev, A. P., 1968, Biology of the Juvenile Pink Salmon and the Chum Salmon in the Sea, Fisheries, 4, 16-17 [In Russian].

Kaeriyama, M., 1989, Aspects of Salmon Ranching in Japan, Physiol. Ecol. Jpn. Spec., 1, 625-638.

Kaeriyama, M., 1996, Changes in Body Size and Age at Mature of a Chum Salmon Oncorhynchus keta, Population Released from Hokkaido in Japan, Doc. NPAFC, 208.

Kaeriyama, M.; Seo, H.; Urawa, S., 2008, Perspective on Production Trends and Carrying Capacity of Pacific Salmon in the North Pacific, BASIS Symposium.

Karpenko, V. I., 1981, Food Supply and Nutrition of Juvenile Pink Salmon (Oncorhynchus gorbuscha Walbaum) and Chum Salmon (Oncorhynchus keta Walbaum) in the Coastal Waters of the Karaginsky Bay of the Bering Sea, Journal of Ichthyology, 21, Iss. 4, 675-685 [In Russian].

Karpenko, V. I., 1983, Influence of Environmental Factors on the Formation of Quality Parameters of the Juvenile Far Eastern Pacific Salmon of the Genus Oncorhynchus (Salmonidae) in the Kamchatka Waters of the Bering Sea, Ibid., 23, Iss. 5, 813-820 [In Russian].

Karpenko, V.I., 1998, Early Marine Period Life of the Pacific Salmon, Moscow, VNIRO [In Russian].

Karpenko, V. I.; Andrievskaya, L. D.; Koval, M. V., 2013, Food and Growth Characteristics of Pacific Salmon in the Marine Waters, Petropavlovsk-Kamchatsky, KamchatNIRO [In Russian].

Karpenko, V. I.; Koval, M. V., 2012, Feeding Strategies and Trends of Pink and Chum Salmon Growth in the Marine Kamchatka Waters, NPAFC Technical Rep., 8, Vancouver, Canada, 82-86.

Klokov, V. K., 1970, On the Issue of the Dynamics of Salmon Spawning Stocks at the Northern Coast of the Sea of Okhotsk, Izvestiya TINRO, 71, 169-177 [In Russian].

Klokov, V. K., 1973, Variability of Size and Weight Parameters of the Chum Salmon at the Northern Coast of the Sea of Okhotsk, Ibid., 86, 81-100 [In Russian]. 
Klokov, V. K., 1975, Population Structure and Dynamics of the Chum Salmon at the Northern Coast of the Sea of Okhotsk, Author's Abstract, Diss. Cand. Sci. (Biology), Vladivostok, TINRO [In Russian].

Klovach, N. V., 2003, Ecological Consequences of the Large-Scale Chum Salmon Breeding, Moscow, VNIRO [In Russian].

Kostarev, V. L., 1964, Some Regularities in the Fluctuating Population of the Okhotsk Pacific Salmon, Salmon Fishery in the Far East, Moscow, Nauka, 77-83 [In Russian].

Kostarev, V. L., 1967, Age and Growth of the Okhotsk Chum Salmon, Izvestiya TINRO, 61, 173-181 [In Russian].

Kostarev, V. L., 1970, Chum Salmon Fishing, Ibid., 71, 133-143 [In Russian].

Koval, M. V., 2009, Features of Fish Growing and PreSpawning Migrations of the Pacific Salmon in the Kamchatka Waters in the Summer of 2009, Bull. No. 4 on Implementing the Concept of the Far East Basin Program for the Pacific Salmon Study, Vladivostok, TINRO-Center, 150-158 [In Russian].

Kulbachny, S. E.; Ivankov, V.N., 2011, Temporal Differentiation and Breeding Conditions of the Chum Salmon Oncorhynchus keta (Salmoniformes: Salmonidae) in the Tugur River Basin (Khabarovsk Krai), Journal of Ichthyology, 51, 1, 70-79 [In Russian].

Kulikova, N. I., 1972, Variability and Ways of Intermutation in the Chum Salmon Oncorhynchus keta (Walb.), Ibid., 12, Iss. 2 (73), 211-225 [In Russian].

Kuzishchin, K.V.; Gruzdeva, M. A.; Savvaitova, K. A.; Pavlov, D. S.; Stanford, D. A., 2010, Seasonal Races of the Chum Salmon Oncorhynchus keta and Their Interrelations in the Rivers of Kamchatka, Ibid., 50, 2, 202-215 [In Russian].

Levanidov, V. Ya., 1969, Reproduction of the Amur River Pacific Salmon and the Forage Base for Their Juveniles in the Tributaries of the Amur River, Izvestiya TIN$R O, 67$ [In Russian].

Lovetskaya, E. A., 1948, Materials on the Biology of the Amur River Chum Salmon, Ibid., 27, 115-137 [In Russian].

Markina, N.P.; Chernyavsky, V.I., 1984, Quantitative Distribution of Plankton and Benthos in the Sea of Okhotsk, Ibid., 109, 109-119 [In Russian].

Mednikov, B. M.; Volobuev, V. V.; Gorshkov, V. A.; Maksimov, V. A.; Savoskul, S. P.; Tsarev, Yu. I., 1988, Spawning Population Structure of the Chum Salmon Oncorhynchus keta in the Tauy River Basin ( by the Data from Molecular Hybridization of DNA), Journal of Ichthyology, 28, 5, 724-731 [In Russian].

Nikolayeva, E. T., 1974, On the Kamchatka Chum Salmon Fecundity, Izvestiya TINRO, 90, 145-172 [In Russian].

Nikolayeva, E. T.; Ovchinnikov, K. A., 1988, On the Intraspecific Structure of the Chum Salmon Oncorhynchus keta in Kamchatka, Journal of Ichthyology, 28, 3, 493496 [In Russian].

Nikolayeva, E. T.; Zavarina, L. O.; Nikolayeva, A. A., 1995, Morphological Description of the "Spring" and "Summer" Chum Calmon Oncorhynchus keta in the Kamchatka River (Kamchatka), Sbornik Nauchnykh Trudov KamchatNIRO, Iss. 3, 125-129 [In Russian].

Odum, Yu., 1986, Ecology, Moscow, Mir, Vol. 2 [In Russian].
Ogura, M.; Ishida, Y.; Ito, S., 1991, Growth Variation of Coho Salmon Oncorhynchus kisutch in the Western North Pacific, Nippon Suisan Gakkaishi, 57, 1089-1093.

Peterman, R. M., 1984, Density-Dependent Growth in Early Ocean Life of Sockeye Salmon (Oncorhynchus nerka), Can. J. Fish. Aquat. Sci., 41, 1825-1829.

Peterman, R. M., 1991, Density-Dependent Marine Processes in North Pacific Salmonids: Lessons for Experimental Design of Large-Scale Manipulations of Fish Stocks, ICES Mar. Sci. Symp., 192, 69-77.

Platoshina, L. K., 1984, Biological Parameters of Summer Chum Salmon from Different Rivers of the Amur River Basin, Biology of Anadromous Fish in the Far East, Vladivostok, DVGU, 57-64 [In Russian].

Pratt, D. C., 1974, Age, Sex, Length, Weight, and Scarring of Adult Chum Salmon (Oncorhynchus keta) Harvested by Puget Sound Commercial Net Fisheries from 1954 to 1970: Supplemental Progress Report, Mar. Fish. Invest. Olympia, Wash. Dep. Fish and Wildlife.

Pravdin, I. F., 1940, Review of Far Eastern Pacific Salmon Studies, Izvestiya TINRO, 18 [In Russian].

Pravdin, I. F., 1966, Manual of Studying Fish, Moscow, Pishchevaya Promyshlennost [In Russian].

Putivkin, S. V., 1989, On the Formation of the Hydrological Regime at the Spawning Grounds of the Anadyr River Chum Salmon, Journal of Ichthyology, 29, 1, 96103 [In Russian].

Putivkin, S. V., 1999, Biology and Population Dynamics of the Anadyr River Chum Salmon, Author's Abstract, Dis. Cand. Sci. (Biology), Vladivostok [In Russian].

Ricker, W.E., 1995, Trends in the Average Size of Pacific Salmon in Canadian Catches, Can. Spec. Publ. Fish. Aquat. Sci., 121, 593-602.

Rogers, D. E., 1980, Density-Dependent Growth of Bristol Bay Sockeye Salmon, ed. W. J. McNeil and D. C. Himsworth, Salmonid Ecosystems of the North Pacific, Oregon State University Press, Corvallis, OR, 267-283.

Salmon-2000, 2000, Fishing Season Forecast, Vladivostok, TINRO-Center [In Russian].

Salmon-2001, 2001, Fishing Season Forecast, Vladivostok, TINRO-Center [In Russian].

Salmon-2002, 2002, Fishing Season Forecast, Vladivostok, TINRO-Center [In Russian].

Salmon-2003, 2003, Fishing Season Forecast, Vladivostok, TINRO-Center [In Russian].

Salmon-2004, 2004, Fishing Season Forecast, Vladivostok, TINRO-Center [In Russian].

Salmon-2005, 2005, Fishing Season Forecast, Vladivostok, TINRO-Center [In Russian].

Salmon-2006, 2006, Fishing Season Forecast, Vladivostok, TINRO-Center [In Russian].

Salmon-2007, 2007, Fishing Season Forecast, Vladivostok, TINRO-Center [In Russian].

Salmon-2008, 2008, Fishing Season Forecast, Vladivostok, TINRO-Center [In Russian].

Salmon-2009, 2009, Fishing Season Forecast, Vladivostok, TINRO-Center [In Russian].

Salmon-2010, 2010, Fishing Season Forecast, Vladivostok, TINRO-Center [In Russian].

Salmon-2011, 2011, Fishing Season Forecast, Vladivostok, TINRO-Center [In Russian].

Salmon-2012, 2012, Fishing Season Forecast, Vladivostok, TINRO-Center [In Russian]. 
Salmon-2013, 2013, Fishing Season Forecast, Vladivostok, TINRO-Center [In Russian].

Salmon-2014, 2014, Fishing Season Forecast, Vladivostok, TINRO-Center [In Russian].

Shershneva, V. I.; Koval, M. V., 2004, Caloric Content of the Mass Species of Zooplankton and Ichthyoplankton in Kamchatka Waters, Izvestiya TINRO, 139, 349-369 [In Russian].

Smirnov, A. G., 1947, State of the Amur River Pacific Salmon Stocks and the Causes of Their Numerical Fluctuations, Ibid., 25, 33-51 [In Russian].

Smirnov, A. I., 1975, Biology, Reproduction, and Development of the Pacific Salmon, Moscow, Izd-vo MGU [In Russian].

Starovoytov, A. N., 2003, Chum Salmon (Oncorhynchus keta (Walbaum)) in the Far East Seas: Biological Characteristic of the Species. 1. Seasonal Distribution and Migrations of the Chum Salmon in the Far East Seas and Open Waters of the Northwest Pacific, Izvestiya TIN$R O, 132,43-81$ [In Russian].

Todd, I. S., 1966, A Technique for the Enumeration of Chum Salmon Fry in the Fraser River, British Columbia, Can. Fish. Cult., 38, 3-35.

Volobuev, V. V., 1983, On Intraspecific Differentiation of the Tauy River Chum Salmon (Northern Coast of the Sea of Okhotsk), Abstracts of the 10 $0^{\text {th }}$ All-Union Symposium "Biological Problems of the North", Magadan, Part 2, 155-156 [In Russian].

Volobuev, V.V., 1984, On the Reproduction of Chum Salmon Oncorhynchus keta (Walbaum) (Salmonidae) and the Ecology of Its Juveniles in the Tauy River, Journal of Ichthyology, 24, 6, 953-963 [In Russian].

Volobuev, V. V., 1986, On Intraspecific Heterogeneity of the Chum Salmon Oncorhynchus keta (Walbaum) at the Continental Coast of the Sea of Okhotsk, Abstracts of the $11^{\text {th }}$ All-Union Symposium "Biological Problems of the North”, Yakutsk, 4, 22-23 [In Russian].

Volobuev, V. V., 2000, Long-Term Changes in the Biological Parameters of Chum Salmon of the Okhotsk Sea, Bull. NPAFC, 2, 175-180.

Volobuev, V. V.; Bachevskaya, L. T.; Volobuev, M.V.; Marchenko, S. L., 2005, Population Structure of the Chum Salmon Oncorhynchus keta (Walbaum) at the Continental Coast of the Sea of Okhotsk, Journal of Ichthyology, 45, 4, 489-501 [In Russian].

Volobuev, V. V.; Golovanov, I. S., 2001, Resources of the Pacific Salmon in Magadan Oblast, Sbornik Nauchnykh Trudov MagadanNIRO, 1, 123-133 [In Russian].
Volobuev, V. V.; Marchenko, S. L., 2011, Pacific Salmon at the Continental Coast of the Sea of Okhotsk, Magadan, MagadanNIRO [In Russian].

Volobuev, V. V.; Rogatnykh, A. Yu., 1997, Reproduction Conditions of the Pacific Salmon of the Genus Oncorhynchus at the Continental Coast of the Sea of Okhotsk, Journal of Ichthyology, 37, 5, 612-618 [In Russian].

Volobuev, V. V.; Rogatnykh, A. Yu.; Kuzishchin, K. V., 1990, On the Intraspecific Forms of the Chum Salmon Oncorhynchus keta at the Continental Coast of the Sea of Okhotsk, Ibid., 30, 2, 221-228 [In Russian].

Volobuev, V. V.; Rogatnykh, A. Yu.; Kuzishchin, K. V.; Tsarev, Yu. I., 1992, Morphological Differentiation of the Early and Late Chum Salmon Oncorhynchus keta (Walb.) in the Tauy River, Population Biology of Pacific Salmon in Northeast Asia, Vladivostok, DVO AN SSSR, 72-80 [In Russian].

Volobuev, V. V.; Volobuev, M. V., 2000, Ecology and Structure of Populations as the Main Elements of the Formation of the Chum Salmon Oncorhynchus keta Life Strategy at the Continental Coast of the Sea of Okhotsk, Journal of Ichthyology, 40, 4, 510-529 [In Russian].

Yefimkin, A. Ya., 2003, Pacific Salmon Nutrition in the Western Part of the Bering Sea in the Summer-Autumn Period of 2002, Izvestiya TINRO, 134, 120-134 [In Russian].

Yerokhin, V. G., 1998, Distribution and Biological Parameters of the Juvenile Salmon Oncorhynchus nerka (Walbaum) (Salmonidae) in the Eastern Part of the Sea of Okhotsk, Sbornik Nauchnykh Trudov KamchatNIRO, Iss. 4, 124-130 [In Russian].

Yevzerov, A. V., 1983, Spawning Fund of the Okhotsk and Anadyr Chum Salmon, Biological Foundations of the Development of Salmon Fishery in the Waters of the USSR, Moscow, Nauka, 103-113 [In Russian].

Zavarina, L. O., 2005, Trends in the Changes Abundance of theChum Salmon in the North-East of Kamchat$\mathrm{ka}$ and the Dynamics of Its Biological Parameters, $M a$ terials of the VI Scientific Conference (PetropavlovskKamchatsky, November 29-30, 2005), PetropavlovskKamchatsky, Kamchatpress, 44-47 [In Russian].

Zavarina, L. O., 2006, On the Change of the Biological Parameters of the Chum Salmon (Oncorhynchus keta) on the North-Eastern Coast of Kamchatka, Trudy VNIRO, 146, 211-226 [In Russian]. 